\title{
Aerial glyphosate application reduces grey willow (Salix cinerea) canopy cover, increases light availability, and stimulates kahikatea (Dacrycarpus dacrydioides) growth
}

\author{
James W. Griffiths* and Kate G. McAlpine \\ Department of Conservation, 18-32 Manners Street, Wellington, New Zealand \\ *Author for correspondence (Email: jgriffiths@doc.govt.nz) \\ Published online: 1 March 2017
}

\begin{abstract}
Grey willow (Salix cinerea) is widely established in New Zealand's remaining swamps and fens, and in many areas has replaced endemic kahikatea (Dacrycarpus dacrydioides) forest. Conservation managers need to know how to restore willow-invaded wetlands to a resilient natural state, but knowledge on how to achieve this goal is limited. We planted kahikatea seedlings into an intact stand of grey willow and into areas where the herbicides glyphosate or triclopyr had been aerially applied to control willow $\sim 1.5$ years earlier. We measured canopy cover, light availability and the growth of planted kahikatea. In areas treated with glyphosate, grey willow canopy cover was reduced to $44 \% \pm 3.7 \%$ (95\% confidence interval), light availability increased to $64 \% \pm 15 \%$ of full sunlight, and kahikatea grew an average of $44 \mathrm{~cm} \pm 11.7 \mathrm{~cm}$ in 14 months. In contrast, there was little or no kahikatea growth under the intact willow canopy or in the triclopyr treatment area where grey willow canopy cover remained high and mean light availability was low ( $25 \% \pm 4 \%$ of full sunlight). We conclude that the removal of the grey willow canopy through aerial glyphosate application created favourable conditions for the growth of planted kahikatea and may enable the restoration of kahikatea forest in wetlands dominated by grey willow.
\end{abstract}

Key words: biodiversity restoration; glyphosate; triclopyr; weed control; wetland

\section{Introduction}

New Zealand's wetlands have been severely depleted, fragmented and degraded since human colonisation, largely due to land clearance and drainage (McGlone 2009). It is estimated that land development has reduced wetland area by approximately 90\% (McGlone 2009). Wetlands also appear to be extremely vulnerable to weed invasion (Zedler $\&$ Kercher 2004). In New Zealand, grey willow (Salix cinerea L.) and crack willow ( $S$. x fragilis L.) are major invaders of riparian zones and wetlands, having spread widely from populations originally planted for bank stabilisation and wetland reclamation (Champion 1994). Once established, grey and crack willow can outgrow and overtop slower growing native plants (Cremer 2003; Coleman 2010), and can displace or modify indigenous plant communities through shading, changes to hydrology, soil profile and chemistry (Champion 1994; Partridge 1994; Cremer 2003). Native birds, lizards, and insects may also be adversely affected as willows can favour non-native over native species (Balneaves \& Hughey 1990; Lester et al. 1994, 1996; Maloney et al. 1999; Cremer 2003; Watts et al. 2012).

The endemic tree species kahikatea (Dacrycarpus dacrydioides (A. Rich.) de Laubenfels) is impacted significantly by wetland conversion and non-native tree invasion (Wardle 1974; Champion 1988). Kahikatea was once dominant on wet mineralised soils at lower elevations $(<100 \mathrm{~m}$ a.s.l.) throughout New Zealand and formed extensive forests in lowland basins. However, these swamp forests (Johnson \& Gerbeaux 2004) now occupy only $\sim 6 \%$ of their historic extent (Ausseil et al. 2007) and much of the remaining swamp habitat has been colonised by grey and crack willow (Champion 1988). Grey willow is of particular concern, because it spreads rapidly by light, wind-dispersed seed (Cremer 2003; Hopley \& Young 2015) and has considerable niche overlap with kahikatea (Champion 1994).

Although kahikatea seedlings are recorded beneath mature native forest canopies (Smale 1984) and in stands of mature grey willow (Champion 1994), high light availability is necessary for seedling and sapling growth (Smale 1984; Duncan 1993; Champion 1994; Ebbett \& Ogden 1998). Thus, canopy removal is thought to be necessary for successful kahikatea regeneration (Smale 1984; Duncan 1993).

Willow canopy removal can be achieved by felling and removing mature willow trees, but this method is expensive, can damage remaining values, and creates disturbance that may favour reinvasion by willows or other weeds (Dulohery et al. 2000). Thus, poisoning willow trees and leaving them to decompose slowly may be a better control method to facilitate native plant restoration (Peters \& Clarkson 2010). Aerial herbicide application can provide cost effective willow control over large areas (Champion 2005; Hutchinson \& Langeland 2010) and may promote suitable conditions for re-establishing kahikatea forest at a large scale.

Restoring kahikatea forest in willow-invaded wetlands may require the reintroduction of native vegetation by sowing seed or planting saplings, as seed sources are often remote. Sowing seed can be a cost-effective method to introduce a high number of propagules to a site, but survival of newly germinated seedlings can be low, especially where there is competition from exotic grasses (Harrington \& Tappeiner 1997). Planting saplings can be costly and labour-intensive (Douglas et al. 2007), but may result in higher survival of plants (Douglas et al. 2007; Schmidt 2008).

This experiment investigated the growth and survival of kahikatea seedlings planted following willow control. We 
expected that an increase in light availability following willow control would promote kahikatea growth and survival. We took advantage of an existing trial comparing the aerial broadcast of two herbicides, glyphosate and triclopyr, for large-scale willow control.

\section{Methods}

\section{Study site}

The study was conducted in a large stand ( $\sim 75$ ha) of mature grey willow $\left(\sim 25\right.$ years old) at Harts Creek $\left(43.79^{\circ} \mathrm{S}\right.$, $172.36^{\circ} \mathrm{E}$ ), a spring-fed freshwater wetland complex on the western margin of Te Waihora (Lake Ellesmere) on the east coast of the South Island of New Zealand. Near the wetland's terrestrial edge, tall $(15-20 \mathrm{~m})$ grey willows dominate areas of high ground ( $0-1 \mathrm{~m}$ above water level) around a series of shallow $(<1.5 \mathrm{~m}$ depth $)$ pools. In these areas grey willows form a dense continuous canopy over native ferns (Blechnum spp., Dicksonia squarrosa, Microsorum pustulatum and Polystichum spp.), native sedges (Carex spp., Isolepis spp., Eleocharis spp. and Machaerina spp.) and shrubs (Coprosma spp. and Melicytus ramiflorus). Further from the wetland edge, soils become increasingly water-logged and the grey willow stand becomes discontinuous and declines in height (1-3 m). Native sedges and rushes (Apodasmia similis, Carex spp. and Juncus spp.) become dominant and are interspersed with scattered Coprosma spp., flax (Phormium tenax), and patches of raupō (Typha orientalis). Exotic pasture grasses (Agrostis spp., Holcus lanatus, and Schedonorus arundinaceus), and blackberry (Rubus fructicosus agg.) are also present.

The climate around Te Waihora is relatively dry and warm, with a high number of days with maximum temperatures $>25^{\circ} \mathrm{C}$ (Renwick et al. 2010). Annual mean rainfall is between 500 and $750 \mathrm{~mm}$ (Renwick et al. 2010). However, despite the dry climate, soils at Harts Creek remain permanently moist as the wetland is spring-fed and groundwater levels are relatively stable.

\section{Herbicide application}

In December 2012, 11 parallel transects $\sim 30$ m wide and $\sim 200 \mathrm{~m}$ long were established perpendicular to the terrestrial margin of the wetland. These were separated by $\sim 50 \mathrm{~m}$ to reduce the likelihood of contamination due to herbicide drift. In February 2013, glyphosate and triclopyr herbicide formulations (Table 1) were applied to four transects each. The remaining three transects received no treatment. Herbicides were applied by helicopter at a mixed volume of $400 \mathrm{~L} \mathrm{ha}^{-1}$ with spray nozzles adjusted to produce droplets of 400 microns mean diameter. Herbicides were released $\sim 5 \mathrm{~m}$ above the grey willow canopy in overlapping swathes flown from opposite directions at a flying speed of $\sim 30$ knots.

\section{Kahikatea planting}

One hundred and sixteen kahikatea seedlings were acquired from Motukara Nursury where they were propagated from seed sourced from the Banks Ecological Region (McEwen 1987) and grown under shade in $2 \mathrm{~L}$ pots for 2-3 years to an average height of $72.3 \mathrm{~cm} \pm 2.1 \mathrm{~cm}(95 \%$ confidence interval). Each kahikatea seedling was each tagged with a unique ID and randomly divided into groups of four plants. In June 2014, $\sim 1.5$ years after herbicide application, kahikatea groups were planted at 2-3 sites on each herbicide and control transect in a square arrangement with $\sim 2 \mathrm{~m}$ spacing between plants. At each planting site, three randomly selected kahikatea seedlings were protected with a Southern Woods Nursery plastic combiguard sheath secured with four bamboo stakes and a woollen mulch mat placed around the seedling base. These seedlings were also fertilised with a Southern Woods Nursery slow release GROTAB fertiliser tablet $(N=20 \%, P=4.3 \%, K=$ $4.1 \%, C a=2.6 \%, S=1.6 \%$ ), which was placed at the base of the planting hole. The remaining kahikatea seedling in each group was planted without a combi-guard, woollen mulch mat or fertiliser tablet. However, soon after planting most of the combi-guards and mulch mats were removed, probably by possums (Trichosurus vulpecula) or pūkeko (Porphyrio porphyrio), and so were unlikely to have conferred much advantage to protected seedlings.

In total, 29 kahikatea groups were planted: 9 on control transects, 12 on glyphosate transects, and 8 on triclopyr transects. On the control and glyphosate transects, kahikatea groups were planted at $\sim 10 \mathrm{~m}, \sim 40 \mathrm{~m}$ and $\sim 70 \mathrm{~m}$ from the start of each transect on the nearest area of ground above water level. On triclopyr transects, kahikatea groups were only planted at $\sim 10 \mathrm{~m}$ and $\sim 40 \mathrm{~m}$ as there were insufficient kahikatea seedlings to plant three sites on each transect. After planting the height $(\mathrm{cm})$ and stem diameter $(\mathrm{mm})($ at $50 \mathrm{~cm}$ above ground level) of all kahikatea were measured: once in June 2014 when seedlings were planted and 14 months later in August 2015.

\section{Light regime}

Canopy cover and light availability during summer were measured at each kahikatea planting site using hemispherical imagery and Hemiview image processing software (Delta-T Devices Ltd 1999). At the centre of each site, three hemispherical photographs were taken $\sim 1.5 \mathrm{~m}$ above the ground at aperture settings $\mathrm{f} / 9, \mathrm{f} / 10$ and $\mathrm{f} / 11$ using a Canon EOS 50D digital SLR camera and a 4.5-mm Sigma EX DC hemispherical (fisheye) lens attached to a self-levelling mount on a tripod. Photos were taken in February 2012 before herbicide application, and $\sim 2$ years after herbicide application in February 2015 near the midpoint of the 14 month kahikatea planting study. Photographs were reviewed in Microsoft Picture Manager and the photo with the clearest focus and best contrast balance

Table 1. Glyphosate and triclopyr herbicide formulations applied to grey willow at Harts Creek.

\begin{tabular}{llll}
\hline Glyphosate & volumes ha $^{-\mathbf{1}}$ & Triclopyr & volumes ha $^{\mathbf{- 1}}$ \\
\hline Glyphosate 360 & $9 \mathrm{~L}(3.24 \mathrm{~kg}$ a.i. $)$ & Garlon $^{\mathrm{TM}} 360$ & $18 \mathrm{~L}(6.48 \mathrm{~kg}$ a.i. $)$ \\
Suprasil® (surfactant) & $1 \mathrm{~L}$ & Elliot Actiwett & $0.2 \mathrm{~L}$ \\
AGPRO Blue Dye & $0.8 \mathrm{~L}$ & AGPRO Blue Dye & $0.8 \mathrm{~L}$ \\
Clean neutral water & $389.2 \mathrm{~L}$ & Clean neutral water & $381 \mathrm{~L}$ \\
\hline
\end{tabular}


selected from each group of bracketed photos. Selected images were analysed using HemiView (Delta-T Devices Ltd 1999) to calculate canopy cover and the percentage of full sunlight (global site factor) for each planting site.

\section{Statistical analysis}

Data were analysed using R 3.1.3 (R Core Team 2016). We used analysis of variance (ANOVA) to determine whether kahikatea growth, canopy cover and the percentage of full sunlight differed between treatments, and a Tukey HSD test to determine which treatments differed significantly from others. Linear regressions were used to investigate relationships between light availability in February 2015 and mean kahikatea height and stem diameter growth. Significance was set at $p<0.05$. There was no difference in mean stem diameter or height growth between seedlings planted with and without combi-guards, mulch mats and fertilizer $(\mathrm{F}=1.132, p=0.29$; $\mathrm{F}=0.435, p=0.47$ ) so data from all kahikatea seedlings were pooled for analysis.

\section{Results}

The aerial application of glyphosate reduced grey willow canopy cover from $76 \% \pm 7 \%$ to $44 \% \pm 3.7 \%$ (Fig. 1 ), and increased the percentage of full sunlight from $28 \% \pm 9 \%$ to $64 \% \pm 15 \%$. However, Tukey HSD tests revealed no significant differences in canopy cover between 2012 and 2015 in the triclopyr treatment $(p=0.89)$ or experimental control $(p=$ 0.44 ) transects (Fig. 1), and light availability was much lower in these areas in $2015(25 \% \pm 4 \%$ of full sunlight $)$ than in the glyphosate treatment transects $(64 \% \pm 15 \%$ of full sunlight).

Kahikatea height and stem diameter growth during the 14 month study period varied between treatments $(\mathrm{F}=12.58$, $p<0.001 ; \mathrm{F}=5.034, p=0.008)$ and reflected differences in light availability in 2015. Both measures were higher in the glyphosate treatment transects than in the triclopyr treatment transects $(p<0.001 ; p=0.022)$ or experimental control areas $(p<0.001 ; p=0.032)$ (Fig. 2). Mean kahikatea height and stem diameter growth in the glyphosate treatment areas were 44 $\mathrm{cm} \pm 11.7 \mathrm{~cm}$ and $3.6 \mathrm{~mm} \pm 1.1 \mathrm{~mm}$ (Fig. 2). In the triclopyr treatment and experimental control areas, no significant change in mean kahikatea height was recorded between 2012 and 2015 $(p=0.403 ; p=0.954)$, but there was an increase in mean stem diameter $(p=0.027 ; p=0.047)$. However, in both treatment areas mean stem diameter growth was low $(1.67 \mathrm{~mm} \pm 0.98$ $\mathrm{mm} ; 1.73 \mathrm{~mm} \pm 0.72 \mathrm{~mm}$ over 14 months; Fig. 2).

The relationship between kahikatea height growth and percentage of full sunlight was significant $\left(\mathrm{r}^{2}=0.41, p<0.001\right)$ implying that, in part, kahikatea growth is explained by light availability (Fig. 3). We also found a significant relationship between kahikatea stem diameter growth and percentage of full sunlight, but the relationship was weak $\left(\mathrm{r}^{2}=0.11, p=\right.$ 0.049) (Fig. 3).

Overall kahikatea mortality was low: only six out of 116 kahikatea planted died, four in the experimental control
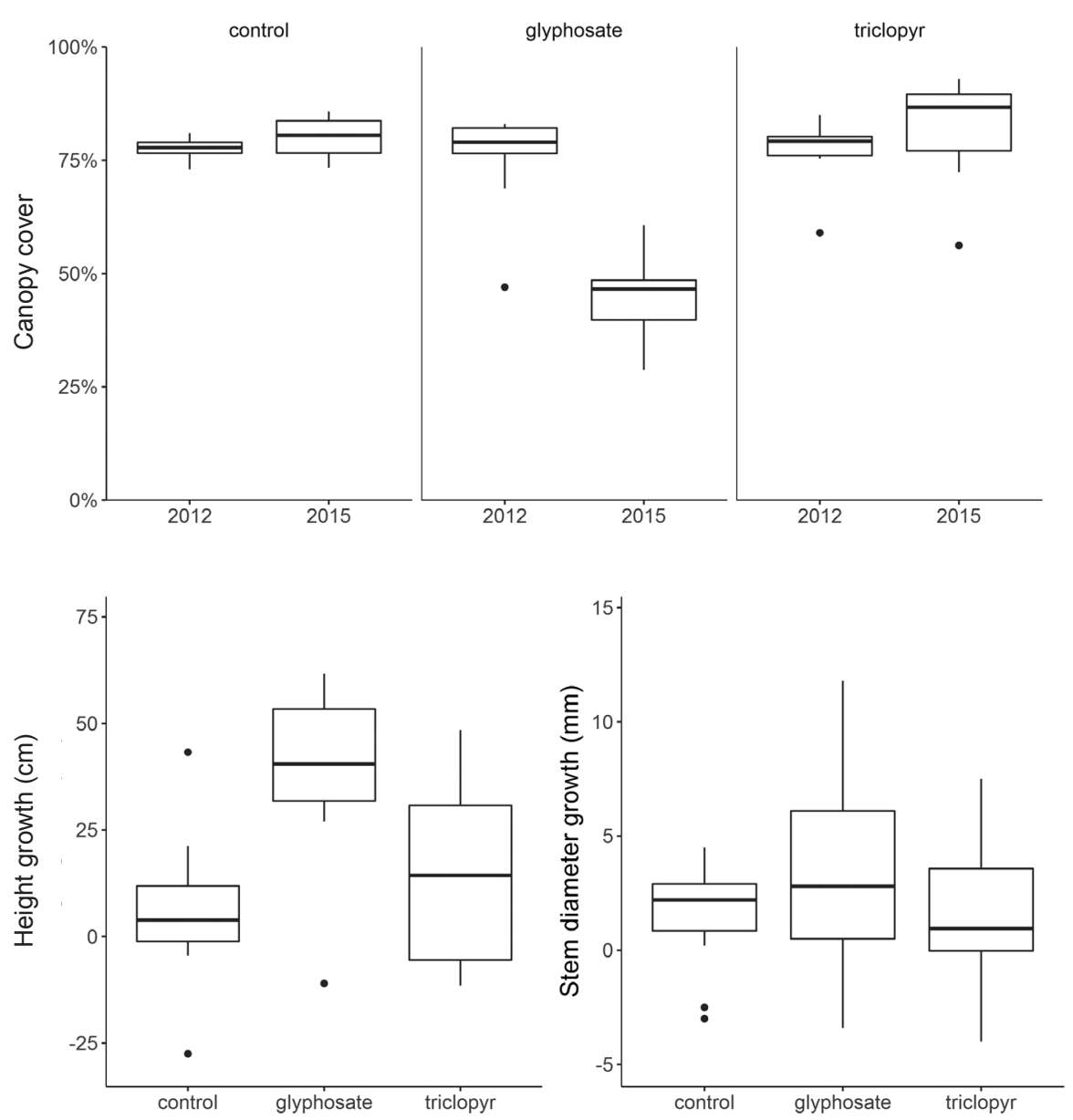

Figure 1. Canopy cover of each treatment before herbicide application in 2012 and after herbicide application in 2015. Box plots show the median and the first and third quartiles in the box. Whiskers are the maximum and minimum values $<1.5$ times the interquartile range. Black dots show outliers, which are $>1.5$ times the interquartile range.
Figure 2. Kahikatea height and stem diameter growth per treatment over the 14 month study period. Box plots show the median, and the first and third quartiles in the box. Whiskers are the maximum and minimum values $<1.5$ times the interquartile range. Black dots show outliers, which are $>1.5$ times the interquartile range. 

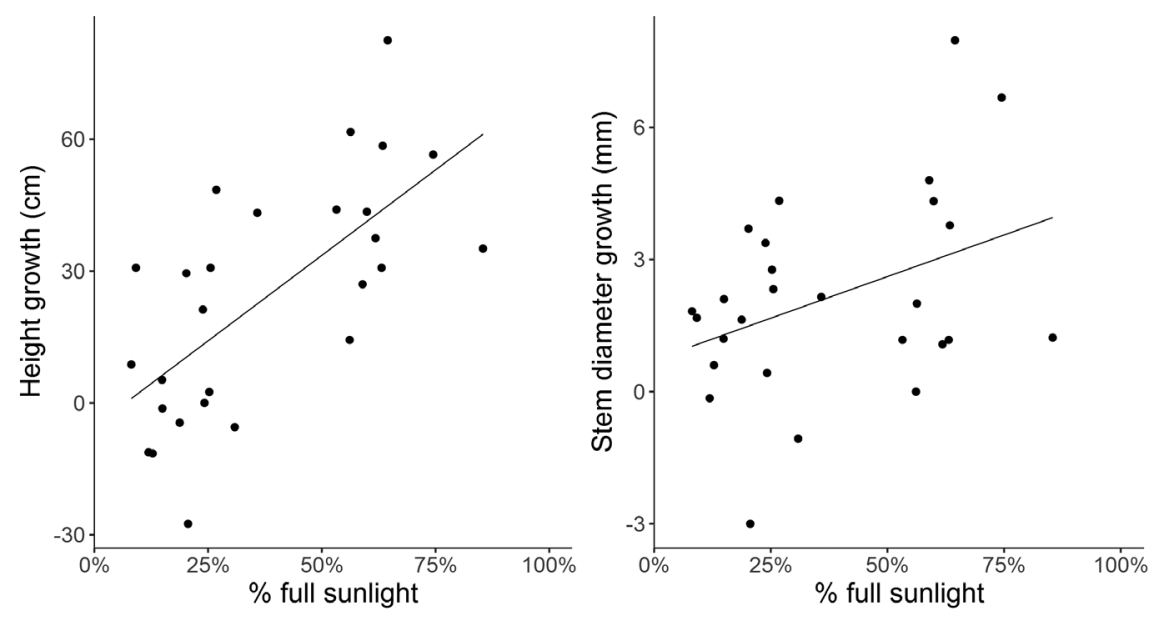

Figure 3. Mean kahikatea height and stem diameter growth as a percentage of full sunlight. area and two in the glyphosate treatment area. However, we recorded dieback of the apical shoot on a number of kahikatea seedlings where the percentage of full sunlight was less than $35 \%$ (Fig. 3).

\section{Discussion}

When seed is not limiting, kahikatea readily establishes extensive even-aged stands on fluvial surfaces after flooding destroys mature forest (Duncan 1993). Kahikatea can also colonise mature native forest and can grow rapidly in canopy gaps where light availability is high (Ebbett \& Ogden 1998). However, high seedling and sapling mortality occurs where kahikatea colonise sites under intact canopy (Wardle 1974; Duncan 1993), and canopy removal is thought to be necessary for successful kahikatea regeneration in mature native forest (Wardle 1974; Smale 1984; Duncan 1993; Ebbett \& Ogden 1998).

We suggest that successful kahikatea regeneration in grey willow dominated wetlands may also depend on canopy removal. In our study, kahikatea height and stem diameter growth were both related to light availability and were highest where glyphosate application significantly reduced grey willow canopy cover. Where light availability was low in the triclopyr treatment and experimental control areas, little or no kahikatea height and stem diameter growth occurred and a number of seedlings suffered apical shoot dieback - a symptom of light deficiency (Takenaka 2000). For shade-intolerant forest trees, individuals with high growth rates are much more likely to survive than those that grow slowly (Kobe \& Coates 1997). This implies that fast growing kahikatea seedlings in high light areas are more likely to survive and reach maturity than slow growing seedlings in shaded areas. It also adds weight to our hypothesis that grey willow canopy removal is necessary for successful kahikatea regeneration.

Other biophysical factors such as nutrient availability, soil moisture and competition may also influence kahikatea growth (Chapin et al. 1987). However, these factors were not measured in our study so we were unable to deteremine their influence. Nevertheless, we conclude that grey willow canopy removal through aerial glyphosate application created favourable conditions for growth of planted kahikatea and may enable the restoration of kahikatea forest in wetlands currently dominated by grey willow.
Restoring kahikatea forest in degraded wetlands may require planting or seed sowing where seed is limiting. In our study, kahikatea survival during the 14 month experimental term was high, indicating planting is a reliable method for establishing kahikatea. Planting is a common restoration practice, and other studies report high survival rates for native species where conditions are favourable (Langer et al. 1999; Sullivan et al. 2009), particularly where weed control is ongoing (MacKay et al. 2011). However, planting trees may not be practical over large areas due to high costs and labour requirements (Douglas et al. 2007). Sowing seed can be a cheaper and less labour-intensive restoration method, although the establishment rate from seed can be low, due to poor germination and competition with other plants (Sessions et al. 2004). Additionally, manual restoration methods can damage low stature wetland plants through trampling, which can create vacant niches vulnerable to colonisation by weeds (Johnson \& Rogers 2003). Aerially broadcasting seed may be an option for reintroducing kahikatea propagules to large areas without disturbing plant communities. This method has been successfully employed for restoration purposes in other countries (Bassett et al. 2015; Xiao et al. 2015).

In the long term, it is beneficial for managers to know how to remove willows from wetlands and prevent them from re-invading. Reinvasion can occur when apparently dead trees re-sprout, possibly due to inadequate herbicide coverage or uptake (Willoughby \& Stokes 2015), and from seed where remaining populations occur within seed dispersal distance, which may be up to 50-100 km (Cremer et al. 1999; Hopley \& Young 2015). However, grey willow are highly shadeintolerant (Končalová \& Jičínská 1985). Thus, restoring the cover and species diversity of native vegetation may increase the resilience of wetlands to willow reinvasion; which has not been investigated to our knowledge. Given the widespread degradation of wetlands in New Zealand, and the potential for grey willow to greatly expand its current distribution, we suggest that the need for such research is urgent.

\section{Acknowledgements}

We thank Craig Alexander and Robin Smith who provided operational support, managed the application of herbicides, and the sourcing and planting of kahikatea. Craig Alexander, Stephen Brailsford (Brailsford ltd), Rachel Innes, JeffHamilton 
(Tramway Reserve Trust), Ian Hankin, Clayson Howell, Helen McCaughan, Anita Spencer and Robin Smith helped with planting kahikatea and measuring growth. Lastly, we thank Clare Veltman, Clayson Howell, Susan Timmins and two anonymous reviewers who gave constructive feedback on the manuscript.

\section{References}

Ausseil A, Dymond JR, Shepherd JD 2007. Rapid mapping and prioritisation of wetland sites in the Manawatu-Wanganui Region, New Zealand. Environmental Management 39: 316-325.

Balneaves J, Hughey K 1990. The need for control of exotic weeds in braided river beds for conservation of wildlife. Proceedings of 9th Australian Weeds Conference. Adelaide. Pp. 103-108.

Bassett OD, Prior LD, Slijkerman CM, Jamieson D, Bowman DM 2015. Aerial sowing stopped the loss of alpine ash (Eucalyptus delegatensis) forests burnt by three shortinterval fires in the Alpine National Park, Victoria, Australia. Forest Ecology and Management 342: 39-48.

Champion PD 1988. The ecology and management of Kahikatea Dacrycarpus dacrydioides (A. Rich) de Laubenfels in the Waikato, North Island, New Zealand. Department of Biological Sciences. Hamilton, New Zealand, University of Waikato. $182 \mathrm{p}$.

Champion PD 1994. Extent of willow invasion - the threats. In: West CJ ed. Proceedings of a willow control workshop. Hamilton, New Zealand, Waikato Conservancy, Department of Conservation. Pp. 43-49.

Champion PD 2005. Evaluation of willow control at Kopuatai, Hauraki Plains. Hamilton, New Zealand, National Institute of Water and Atmospheric Research Ltd. 8 p.

Chapin FS, Bloom AJ, Field CB, Waring RH 1987. Plant responses to multiple environmental factors. Bioscience 37: 49-57.

Coleman EJ 2010. Mechanisms of interference between kahikatea and grey willow in the Waikato. Department of Biological Sciences. Hamilton, New Zealand, University of Waikato. $111 \mathrm{p}$.

Cremer KW 2003. Introduced willows can become invasive pests in Australia. Biodiversity and Conservation 4: 17-24.

Cremer K, Gooey M, Houghton P 1999. Willow management for Australian rivers. Natural Resource Management (Special Issue): 1-22.

Delta-T Devices Ltd 1999. HemiView Canopy Analysis Software. 130 Low Road, Burwell, Cambridge, United Kingdom.

Douglas GB, Dodd MB, Power IL 2007. Potential of direct seeding for establishing native plants into pastoral land in New Zealand. New Zealand Journal of Ecology 31: 143-153.

Dulohery C, Kolka RK, McKevlin M2000. Effects of a willow overstory on planted seedlings in a bottomland restoration. Ecological Engineering 15: S57-S66.

Duncan RP 1993. Flood disturbance and the coexistence of species in a lowland podocarp forest, south Westland, New Zealand. Journal of Ecology 81: 403-416.

Ebbett R, Ogden J 1998. Comparative seedling growth of five endemic New Zealand podocarp species under different light regimes. New Zealand Journal of Botany 36: 189-201.

Harrington TB, Tappeiner JC 1997. Growth responses of young Douglas-fir and tanoak 11 years after various levels of hardwood removal and understory suppression in southwestern Oregon, USA. Forest Ecology and Management 96: 1-11.

Hopley T, Young AG 2015. Knowledge of the reproductive ecology of the invasive Salix cinerea, in its invaded range, assists in more targeted management strategies. Australian Journal of Botany 63: 477-483.

Hutchinson JT, Langeland KA 2010. Evaluation of aerial herbicide application for reduction of woody vegetation in a floodplain marsh. Journal of Aquatic Plant Management 48: 40-46.

Johnson P, Gerbeaux P 2004. Wetland types in New Zealand. Wellington, Department of Conservation. $181 \mathrm{p}$.

Johnson P, Rogers G 2003. Ephemeral wetlands and their turfs in New Zealand. Science for Conservation 230. Wellington, New Zealand, Department of Conservation. 109 p.

Kobe RK, Coates KD 1997. Models of sapling mortality as a function of growth to characterize interspecific variation in shade tolerance of eight tree species of northwestern British Columbia. Canadian Journal of Forest Research 27: 227-236.

Končalová MN, Jičínská D 1985. Differences between ecological niches in juvenile Salix cinerea and $S$. pentandra. Folia Geobotanica et Phytotaxonomica 20: 319-321.

Langer ER, Davis MR, Ross CW 1999. Rehabilitation of lowland indigenous forest after mining in Westland. Science for Conservation 117. Wellington, New Zealand, Department of Conservation. $41 \mathrm{p}$.

Lester PJ, Mitchell SF, Scott D 1994. Effects of riparian willow trees (Salix fragilis) on macro-invertebrate densities in two small Central Otago, New Zealand, streams. New Zealand Journal of Marine and Freshwater Research 28: 267-276.

Lester PJ, Mitchell SF, Scott D 1996. Substrate and shade: mechanisms of willow tree influence on the macroinvertebrate community in Heeney Creek, South Island, New Zealand. Archiv für Hydrobiologie 136: 145-158.

McEwen WM 1987. Ecological regions and districts of New Zealand. New Zealand Biological Resources Centre Publication 5. 63 p.

McGlone MS 2009. Postglacial history of New Zealand wetlands and implications for their conservation. New Zealand Journal of Ecology 33: 1-23.

MacKay DB, Wehi PM, Clarkson BD 2011. Evaluating restoration success in urban forest plantings in Hamilton, New Zealand. Urban Habitats 6.

Maloney RF, Keedwell RJ, Wells NJ, Rebergen AL, Nilsson RJ 1999. Effect of willow removal on habitat use by five birds of braided rivers, Mackenzie Basin, New Zealand. New Zealand Journal of Ecology 23: 53-60.

Partridge TR 1994. Ecological impacts of willows in wetlands. In: West CJ ed. Willow control workshop. Hamilton, New Zealand, Waikato Conservancy, Department of Conservation. Pp. 17-22.

Peters M, Clarkson B 2010. Wetland restoration: a handbook for New Zealand freshwater systems. Lincoln, New Zealand, Manaaki Whenua Press, Landcare Research. 263 p.

R Core Team 2016. R: a language and environment for statistical computing. Version 3.1.3. Vienna, Austria, R Foundation for Statistical Computing.

Renwick J, Horrell G, McKerchar A, Verburg P, Hicks M, Hreinsson E 2010. Climate change impacts on Lake 
Ellesmere (Te Waihora). NIWA Client Report WLG201049, Project: ENC10301. Wellington, New Zealand, National Institute of Water and Atmosphere. 29 p.

Schmidt L 2008. A review of direct sowing versus planting in tropical afforestation and land rehabilitation. Forest \& Landscape Development and Environment Series 10: $22-28$.

Sessions J, Bettinger P, Buckman R, Newton M, Hamann J 2004. Hastening the return of complex forests following fire: the consequences of delay. Journal of Forestry 102: 38-45.

Smale M 1984. White pine bush and an alluvial kahikatea (Dacrycarpus dacrydioides) forest remnant, eastern Bay of Plenty, New Zealand. New Zealand Journal of Botany 22: 201-206.

Sullivan JJ, Meurk C, Whaley KJ, Simcock R 2009. Restoring native ecosystems in urban Auckland: urban soils, isolation, and weeds as impediments to forest establishment. New Zealand Journal of Ecology 33: 60-71.

Editorial board member: Margaret Stanley

Received 9 July 2016; accepted 5 January 2017
Takenaka A 2000. Shoot growth responses to light microenvironment and correlative inhibition in tree seedlings under a forest canopy. Tree Physiology 20: 987-991.

Wardle P 1974. The kahikatea (Dacrycarpus dacrydioides) forest of south Westland. Proceedings of the New Zealand Ecological Society 21: 62-71.

Watts C, Rohan M, Thornburrow D 2012. Beetle community responses to grey willow (Salix cinerea) invasion within three New Zealand wetlands. New Zealand Journal of Zoology 39: 209-227.

Willoughby IH, Stokes VJ 2015. Mixture B New Formulation adjuvant increases the rainfastness and hence effectiveness of glyphosate for rhododendron control. Forestry 88: $172-179$.

Xiao X, Wei X, Liu Y, Ouyang X, Li Q, Ning J 2015. Aerial seeding: an effective forest restoration method in highly degraded forest landscapes of sub-tropic regions. Forests 6: 1748-1762.

Zedler JB, Kercher S 2004. Causes and consequences of invasive plants in wetlands: opportunities, opportunists, and outcomes. Critical Reviews in Plant Science 23: 431-452. 